\title{
BMJ Global Health Global health security: where is the data to inform health system strengthening?
}

\author{
Seye Abimbola, ${ }^{1}$ Stephanie M Topp, ${ }^{2}$ Anna Palagyi, ${ }^{1}$ Ben Marais, ${ }^{3}$ Joel Negin ${ }^{1}$
}

To cite: Abimbola S, Topp SM Palagyi A, et al. Global health security: where is the data to inform health system strengthening?BMJ Glob Health 2017;2:e000481. doi:10.1136/ bmjgh-2017-000481

Handling editor Seye Abimbola

Received 18 July 2017 Accepted 21 July 2017

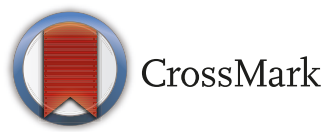

${ }^{1}$ School of Public Health, Sydney Medical School, University of Sydney, Sydney, New South Wales, Australia ${ }^{2}$ College of Public Health, Medical and Veterinary Sciences, James Cook University, Townsville, Queensland, Australia ${ }^{3}$ Marie Bashir Institute for Infectious Diseases and Biosecurity and the Children's Hospital at Westmead, University of Sydney, Sydney, New South Wales, Australia

Correspondence to Dr Seye Abimbola;

seyeabimbola@hotmail.com
The Ebola outbreak in West Africa (20132016) triggered a renewed interest and sense of urgency about global health security. A surge of reports and publications ensued, examining various aspects of emerging infectious disease outbreaks. In 2016, Olivero and colleagues published a biogeographical approach mapping favourable conditions that facilitated the Ebola outbreak, in terms of environmental factors and the presence of potential host animals. ${ }^{1}$ Constructing biological vulnerability maps has value to guide preparations for future emerging infectious disease outbreaks, especially in low-income and middle-income countries. But perhaps more important is the need to develop similar 'vulnerability maps' to capture the ability of health systems to prevent or respond to major infectious disease challenges. Without a health system vulnerability map, or the public availability of the data to generate it, efforts to achieve global health security in relation to emerging infectious disease outbreaks will likely be limited and post hoc, rather than pre-emptive and strategic. Unfortunately, the revived interest in global health security has not been matched with commensurate action. In 2014, the G7 (Group of Seven) endorsed the Global Health Security Agenda (GHSA), a partnership of governments and international organisations with the goal of accelerating the achievement of the core disease outbreak preparedness and response capacities as required by the International Health Regulations, but progress has been limited.

Formal assessment of countries' compliance with International Health Regulations is done through a Joint External Evaluation process. As part of this process, governments essentially assess themselves, followed by an independent international validation of the self-reported assessment. So far, 53 countries have initiated this Joint External Evaluation process. However, despite WHO reports that 43 Joint External Evaluation missions have been completed to date, including six
GHSA-supported assessments completed in $2015,{ }^{2}$ just 23 completed evaluation reports are publicly available online. This exercise is limited in terms of the number of countries covered and the speed with which it is rolled out, but more importantly the evaluations are neither objectively quantifiable nor readily tracked and the relevant measures are only evaluated at the national level. Performance at the subnational level may be as, if not more, important. Indeed, as argued by Glassman and Lofgren (2016), "If we are serious about preventing the spread of emerging infectious diseases..., generating hard data on system performance-not just a rough qualitative approximation-is key to making this global effort successful." ${ }^{3}$ It is important to have a regularly updated database of national and subnational data on key criteria that reflect countries' preparedness and response capacity to disease outbreaks.

For this editorial, we examined the extent to which there is publicly available data on health system input and performance that could inform the judgement as to whether countries are adequately prepared for infectious disease outbreaks or have sufficient response capacity. To do this, we searched online databases to assess which information would be readily available if there was an event that threatened regional/global health security originating in any given country. We included a measure of trust in governments because trust in government has featured prominently in analyses highlighting limitations of national response to the West African Ebola outbreak. ${ }^{4-6}$ We also included factors related to existing accessibility of services (in terms of financial protection, availability of human resources for health, availability of drugs and supplies and quality of service delivery), because effective utilisation of, and trust in, healthcare services is essential to facilitate early case detection. ${ }^{7}$ Together with the quality of existing surveillance systems, we considered these elements to be the major determinants of early outbreak recognition 
and the subsequent course of an outbreak. Further, these elements align with findings of an analysis conducted using the 2002-03 World Health Survey data which indicated that, together, five aspects of health system performance (technical quality, responsiveness, fair treatment, health outcomes, and financial protection) influenced citizens' trust in their government. ${ }^{8}$

We selected the online databases of the WHO, the World Bank and Transparency International to screen for data that may provide proxies for these health system factors. We did not use data from the 2002 to 2003 World Health Survey because we considered it too dated and limited (the study was conducted in 70 countries). For human resources for health, we used data on doctors, nurses and midwives, community health workers and pharmaceutical personnel per 1000 people. For financial protection, we used out of pocket expenditure as a percentage of total expenditure on health. For surveillance, we used tuberculosis treatment success rate for new cases and completeness of death registration with cause-of-death information. For drugs and supplies, we used the median availability of selected generic medicines. For service delivery, we used hospital beds per 1000 people, hospitals and health centres per 100000 people, and antenatal care coverage (of at least four visits). And for our measure of trust, we used Transparency International's Corruption Perception Index.

To assist global and national stakeholders take action on areas for which health systems require strengthening and investment, reputable data should be publicly available. What we found was not encouraging, especially in terms of data to reflect the current conditions of preparedness and response capability for emerging infectious diseases. In the WHO and the World Bank databases, for instance, only four countries had data for 2015. By contrast, current (ie, for 2015) data from Transparency International's Corruption Perception Index exists for 168 countries (see table 1). Such a lack of up-to-date and publicly available data on proxies for health system capacity and infectious disease outbreak preparedness limits the possibility of mapping related vulnerabilities. This in turn limits our capacity to plan for, and invest in, health system strengthening that will promote resilience in the face of such outbreaks. To the best of our knowledge, an equivalent endeavour to Olivero and colleagues' mapping of biological vulnerability to Ebola has not been undertaken for other pathogens, or for biogeographical or health systems vulnerabilities.

It is important that data are collected at regular intervals and made available for international review and transparency purposes. Efforts to assess and evaluate country-level compliance with the International Health Regulations are only one step in a more comprehensive evaluation process. The inclusion of subnational data and expansion beyond the input-focussed indicators of current International Health Regulations assessments are essential. These should include measures of trust (such as the Transparency International proxy used here) and

Table 1 Data availability on health system investment and performance from WHO, World Bank and Transparency International

\begin{tabular}{|c|c|c|c|c|c|c|c|}
\hline \multirow{2}{*}{$\begin{array}{l}\text { Health system investment } \\
\text { and performance measures }\end{array}$} & \multicolumn{7}{|c|}{ Countries with publicly available data, n (\%) } \\
\hline & $2015-$ & $2010-2014$ & $2005-2009$ & $2000-2004$ & $1995-1999$ & -1994 & No Data \\
\hline Doctors per 1000 & $0(0 \%)$ & $161(74 \%)$ & $13(6 \%)$ & $19(9 \%)$ & $12(6 \%)$ & $3(1 \%)$ & $11(5 \%)$ \\
\hline $\begin{array}{l}\text { Community Health Workers } \\
\text { per } 1000\end{array}$ & $0(0 \%)$ & $14(6 \%)$ & $19(9 \%)$ & $38(17 \%)$ & $1(0.5 \%)$ & $1(0.5 \%)$ & $146(67 \%)$ \\
\hline $\begin{array}{l}\text { OOP as } \% \text { of health } \\
\text { expenditure }\end{array}$ & $0(0 \%)$ & $190(87 \%)$ & $0(0 \%)$ & $0(0 \%)$ & $0(0 \%)$ & $0(0 \%)$ & $29(13 \%)$ \\
\hline $\begin{array}{l}\text { New TB treatment success } \\
\text { rate }\end{array}$ & $0(0 \%)$ & $187(85 \%)$ & $0(0 \%)$ & $3(1 \%)$ & $0(0 \%)$ & $0(0 \%)$ & $29(13 \%)$ \\
\hline $\begin{array}{l}\text { Completeness of death } \\
\text { registration }\end{array}$ & $0(0 \%)$ & $88(40 \%)$ & $28(13 \%)$ & $2(1 \%)$ & $1(0.5 \%)$ & $0(0 \%)$ & $100(46 \%)$ \\
\hline Hospital beds per 1000 & $0(0 \%)$ & $155(71 \%)$ & $31(14 \%)$ & $3(1 \%)$ & $5(2 \%)$ & $6(3 \%)$ & $19(9 \%)$ \\
\hline Hospitals per 100000 & $0(0 \%)$ & 137 (63\%) & $0(0 \%)$ & $0(0 \%)$ & $0(0 \%)$ & $0(0 \%)$ & $82(37 \%)$ \\
\hline Health centres per 100000 & $0(0 \%)$ & $112(51 \%)$ & $0(0 \%)$ & $0(0 \%)$ & $0(0 \%)$ & $0(0 \%)$ & $107(49 \%)$ \\
\hline Antenatal care coverage & $4(2 \%)$ & $118(54 \%)$ & $20(9 \%)$ & $1(0.5 \%)$ & $0(0 \%)$ & $0(0 \%)$ & $76(35 \%)$ \\
\hline Corruption Perception Index & $168(76 \%)$ & $0(0 \%)$ & $0(0 \%)$ & $0(0 \%)$ & $0(0 \%)$ & $0(0 \%)$ & $52(24 \%)$ \\
\hline
\end{tabular}

OOP, out of pocket; TB, tuberculosis. 
evaluations of the interoperability of subnational and national healthcare and communication systems to assess the potential of rapid response during outbreaks. Efforts must also extend to the inclusion of animal surveillance and assessments of environmental determinants of potential emerging disease outbreaks.

How should these data be collected and curated? The scope of effort and cost of ensuring the currency and completeness of such a complex global data set is enormous and, as recently argued in BMJ Global Health ${ }^{9}$ and in the Lancet, ${ }^{10}$ potentially beyond the operational capabilities of the WHO. Yet the WHO has a critical role to play in terms of exercising normative authority. ${ }^{11}$ Here, we offer two (of several) possibilities. One, WHO could partner with the G7's Global Health Security Agenda to conduct Joint External Evaluations to assess national compliance on a biennial basis, with regular surveys similar to the Demographic Health Surveys. Second, using the Global Burden of Disease model, WHO could partner with the Institute for Health Metrics and Evaluations and a vast network of (free) collaborators to endorse a new arm of the Global Burden of Disease endeavour, to produce a new biannual or tri-annual comparative health systems evaluation. To ensure a more sophisticated approach to evaluating health system capabilities, this could include collaborations with agencies such as Transparency International to fine tune and better focus assessments of health system processes and perceptions, including measures of trust in government on issues related to healthcare and infectious disease outbreak management.

To accelerate the achievement of outbreak preparedness and response capacities, and to appropriately inform recent calls for improvements in global health security, such improvements in availability and completeness of health system data must be accompanied by the investment necessary to strengthen health systems globally, at national and subnational levels. Further, these health system data should be integrated with biogeographical data, such as ecological and environmental data on potential areas of disease outbreak. With the focus of the Sustainable Development Goals on Universal Health Coverage, it is important to also emphasise the health systems strengthening requirements of global health security, ${ }^{12}$ and the links between achieving those and preparedness for outbreaks and resilience in the face of outbreaks.

Correction notice This article has been corrected since it first published online. The middle initial of the second author has been added and her affiliation changed.

\section{Competing interests None declared.}

Provenance and peer review Not commissioned; internally peer reviewed.

Open Access This is an Open Access article distributed in accordance with the Creative Commons Attribution Non Commercial (CC BY-NC 4.0) license, which permits others to distribute, remix, adapt, build upon this work non-commercially, and license their derivative works on different terms, provided the original work is properly cited and the use is non-commercial. See: http://creativecommons.org/ licenses/by-nc/4.0/

(C) Article author(s) (or their employer(s) unless otherwise stated in the text of the article) 2017. All rights reserved. No commercial use is permitted unless otherwise expressly granted.

\section{REFERENCES}

1. Olivero J, Fa JE, Real R, et al. Mammalian biogeography and the Ebola virus in Africa. Mamm Rev 2017;47:24-37.

2. JEE Alliance.https://www.jeealliance.org/global-health-security-andihr-implementation/joint-external-evaluation-jee/

3. Glassman A, Lofgren K. Getting serious on Global Health Security: Center For Global Development, 2016. https://www.cgdev.org/blog/ getting-serious-global-health-security

4. Blair RA, Morse B, Tsai L. Public Health and Public Trust: evidence from the Ebola virus disease epidemic in Liberia, 2016. https://ssrn. com/abstract $=2864029$

5. Pieterse P, Lodge T. When free healthcare is not free. Corruption and mistrust in Sierra Leone's primary healthcare system immediately prior to the Ebola outbreak. Int Health 2015;7:400-4.

6. Thiam S, Delamou A, Camara S, et al. Challenges in controlling the Ebola outbreak in two prefectures in Guinea: why did communities continue to resist? The Pan African Medical Journal 2015;22(Suppl 10 http://doi.org/10.11694/pamj.supp.2015.22.1.6626

7. Weissman JS, Stern R, Fielding SL, et al. Delayed access to health care: risk factors, reasons, and consequences. Ann Intern Med 1991;114:325-31.

8. Rockers PC, Kruk ME, Laugesen MJ. Perceptions of the health system and public trust in government in low- and middle-income countries: evidence from the World Health surveys. J Health Polit Policy Law 2012;37:405-37.

9. Negin J, Dhillon R. Outsourcing: how to reform WHO for the 21st Century. BMJ Global Health 2017;2:e000107.

10. Horton R. Offline: A unique opportunity for WHO. Lancet 2017;389:2458.

11. Gostin LO, Sridhar D, Hougendobler D. The normative authority of the World Health Organization. Public Health 2015;129:854-63.

12. Jain $V$, Alam $A$. Redefining universal health coverage in the age of global health security. BMJ Glob Health 2017;2:e000255. 


\section{Correction: Global health security: where is the data to inform health system strengthening?}

Abimbola S, Topp SM, Palagyi A, et al. Global health security: where is the data to inform health system strengthening? BMJ Glob Health 2017;2:e000481.

This article has been corrected since it first published online. The middle initial of the second author has been added and her affiliation changed.

Open Access This is an Open Access article distributed in accordance with the Creative Commons Attribution Non Commercial (CC BY-NC 4.0) license, which permits others to distribute, remix, adapt, build upon this work non-commercially, and license their derivative works on different terms, provided the original work is properly cited and the use is non-commercial. See: http://creativecommons.org/licenses/by-nc/4.0/

(C) Article author(s) (or their employer(s) unless otherwise stated in the text of the article) 2017. All rights reserved. No commercial use is permitted unless otherwise expressly granted.

BMJ Glob Health 2017;2:e000481corr1. doi:10.1136/bmjgh-2017-000481corr1 